\title{
A Guidance Document for Kentucky's Oil and Gas Operations
}

\author{
Quarterly Report \\ October 1 - December 31, 1997
}

Work Performed Under Contract No.: DE-FG22-94MT94006

\author{
For \\ U.S. Department of Energy \\ Office of Fossil Energy \\ Federal Energy Technology Center \\ P.O. Box 880 \\ Morgantown, West Virginia 26507-0880 \\ By \\ Commonwealth of Kentucky \\ Department of Mines and Minerals \\ Division of Oil and Gas \\ P. O. Box 14090 \\ Lexington, Kentucky 40512-4090
}




\section{Disclaimer}

This report was prepared as an account of work sponsored by an agency of the United States Government. Neither the United States Government nor any agency thereof, nor any of their employees, makes any warranty, express or implied, or assumes any legal liability or responsibility for the accuracy, completeness, or usefulness of any information, apparatus, product, or process disclosed, or represents that its use would not infringe privately owned rights. Reference herein to any specific commercial product, process, or service by trade

name, trademark, manufacturer, or otherwise does not necessarily constitute or imply its endorsement, recommendation, or favoring by the United States Government or any agency thereof. The views and opinions of authors expressed herein do not necessarily state or reflect those of the United States Government or any agency thereof. 


\section{A GUIDANCE DOCUMENT FOR KENTUCKY'S OIL AND GAS OPERATORS}

DE-FG22-94MT94006--11

Quarterly Technical Progress Report

Reporting Period: 10/01/97 -12/31/97

Commonwealth of Kentucky

Department of Mines and Minerals

Division of Oil and Gas

P. O. Box 14090

Lexington, KY 40512-4090 


\title{
“U.S. DOE PATENT CLEARANCE IS NOT REQUIRED PRIOR TO PUBLICATION OF THIS DOCUMENT"
}

\author{
TECHNICAL PROGRESS REPORT \\ December 31, 1997
}

This technical report is a summary of the progress made for "A Guidance Document for Kentucky's Oil and Gas Operators". During this quarter, the document received continued review and editing in an electronic format to satisfy the United States Department of Energy (DOE). Comments received from oil and gas operators reviewing this document prompted contact to be made with the United States Environmental Protection Agency (USEPA) to develop an addendum section to provide better explanation of USEPA requirements for Class II injection wells in Kentucky.

Some delays in the Guidance Document were encountered this quarter. The subcommittee felt it necessary to obtain a consultant familiar with both state and USEPA requirements for operators of Class II, UIC wells in Kentucky and how they relate to oil and gas industry issues. The consultant was necessary to fill a void not currently available with the subcommittee members, and be able to bridge the gap between state, federal and industry concerns. Subcommittee meetings were cancelled this quarter awaiting the approval of the consultant.

During the next quarter, meetings of the subcommittee and Region IV of the USEPA to develop the addendum section will be scheduled. 